\title{
Carnitine palmitoyltransferase-II deficiency: case presentation and review of the literature
}

\author{
BENJAMIN J. MCCORMICK, RAZVAN M. CHIRILA
}

Department of Internal Medicine, Mayo Clinic, 4500 San Pablo Rd S, Jacksonville, FL 32224

\begin{abstract}
Carnitine palmitoyltransferase-II deficiency, an autosomal recessive disorder, is the most common cause of recurrent rhabdomyolysis in adults. Recognition and avoidance of triggers, such as heavy exercise and stress, is key in prevention of further episodes; however, even with preventative measures, many patients will continue to experience periodic symptoms, including rhabdomyolysis. Avoidance of renal failure, correction of electrolyte disturbances and halting further muscle breakdown are the goals of treatment. It is essential for clinicians to recognize the signs and symptoms of acute disease in CPT-II deficiency. We present a case of recurrent rhabdomyolysis requiring hospitalization in a patient with CPT-II deficiency and review the literature for common clinical manifestations, diagnostics, and treatment strategies.
\end{abstract}

Key words: Carnitine palmitoyltransferase-II deficiency, rhabdomyolysis, myopathy.

\section{INTRODUCTION}

Carnitine palmitoyltransferase-II (CPT-II) deficiency, an autosomal recessive disorder, is the most common inherited disorder of longchain fatty acid oxidation as well as the most common cause of recurrent rhabdomyolysis in adults. To briefly review, carnitine palmitoyltransferase I and II are proteins that facilitate the transfer of long-chain fatty acids from cytoplasm into mitochondria during beta-oxidation of fatty acids for energy production. [Figure 1] Longchain fatty acid oxidation is useful for generating energy in times of stress, such as heavy or prolonged exercise, fasting, cold exposure, and emotional stress. Accordingly, CPT-II deficiency often manifests clinically during these periods of excess stress, as acylcarnitine is only partially transported across the inner mitochondrial membrane leading to insufficient acyl-CoA available for oxidation.

There are three main phenotypes of CPT-II deficiency. Two of three types cause severe hypoketotic hypoglycemia and are lethal in utero or in early neonatal life. The third type, also known as "adult form", is the classical muscle form known to be mild with recurrent episodes of myalgia, muscle weakness and rhabdomyolysis triggered by prolonged exercise. Some individuals are asymptomatic most of their lives, whereas others experience frequent myalgias with severe, frequent attacks of rhabdomyolysis. [1]

We describe the case of a patient with history of CPT-II deficiency who presented with recurrent rhabdomyolysis requiring hospitallization.

\section{CASE PRESENTATION}

A 50-year-old male was admitted to the general hospital internal medicine service with a 2-day history of malaise and lower extremity myalgias that progressed to generalized weakness and dark-colored urine. He denied recent trauma, rash, arthralgias, sick contacts or travel. The patient had experienced over a dozen similar episodes in the past, many of which requiring brief hospitalization for the diagnosis of rhabdomyolysis.

He had a past medical history of GERD, irritable bowel syndrome, obstructive sleep apnea, anxiety, and carnitine palmitoyltransferase-II (CPT-II) deficiency. The patient's home medication regimen included levocarnitine 800 $\mathrm{mg}$ three times daily and medium chain fatty acids three times daily with meals. He was a remote 15-pack-year smoking history (cessation greater than 15 years prior). He consumed roughly 1-3 standard alcohol drinks weekly and reported no prior use of recreational drugs. 


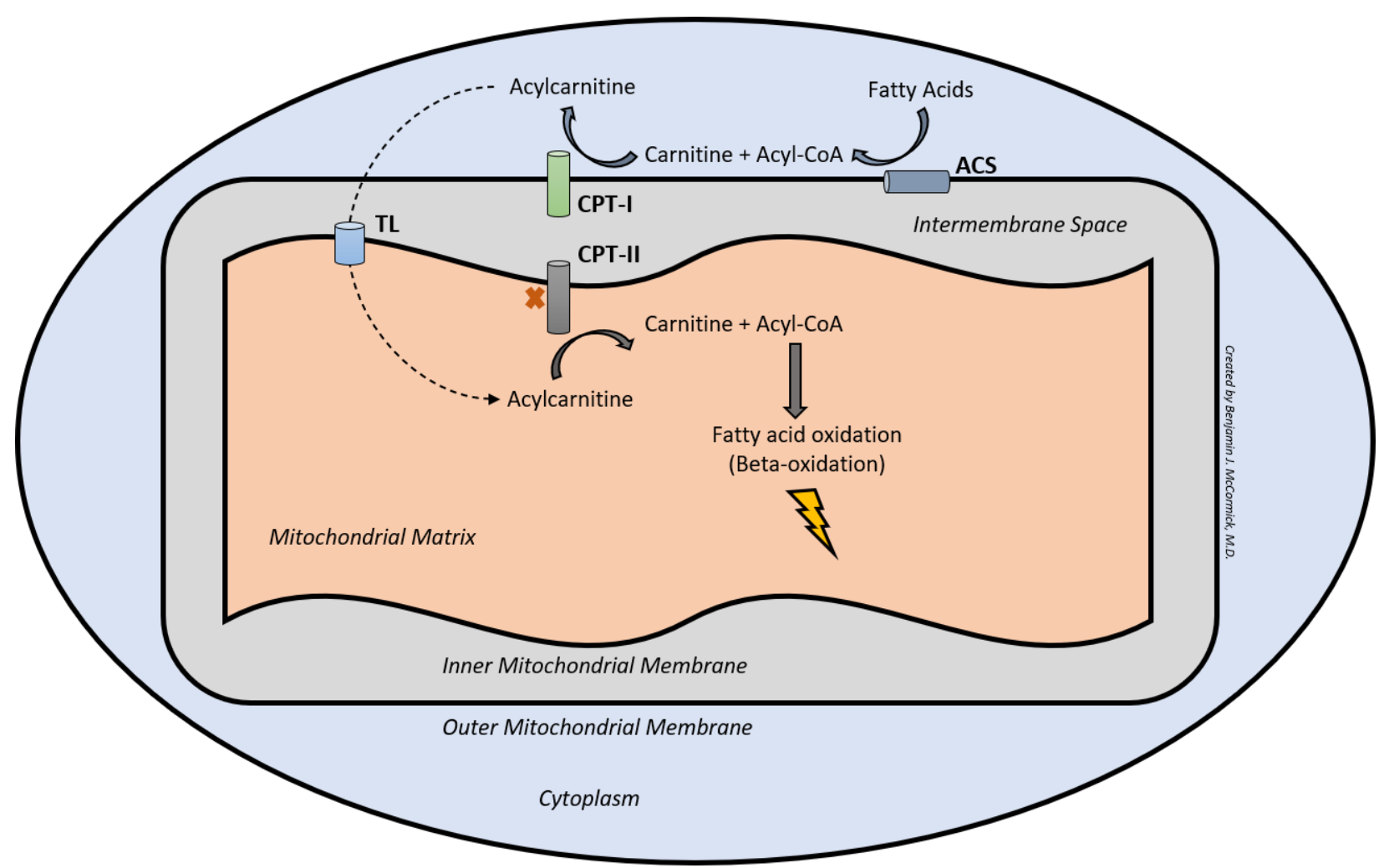

Figure 1. Transport system utilized in myocytes for esterification of fatty acids throughout mitochondrial membranes, which is dysregulated in CPT-II deficiency leading to diminished energy stores during periods of stress, such as prolonged exercise. (CPT I \& II: carnitine palmitoyltransferase I and II; TL: Translocase; CoA: Coenzyme A).

On initial presentation, he was mildly distressed due to myalgias, but he remained alert and oriented. Vital signs were within normal limits. Physical examination revealed grade 5/5 muscle strength throughout with normal sensation, gait and tendon reflexes. Generalized muscle tenderness was present in bilateral lower extremities. Urinalysis with microscopic analysis was moderately positive for hemoglobin and negative for red blood cells. Initial laboratory analysis (reference ranges provided in parentheses) revealed a markedly elevated creatine kinase (CK) level at 47,650 U/L (39-308 $\mathrm{U} / \mathrm{L})$. Given that the creatine kinase was significantly greater than 10 times the upper limit of normal of $308 \mathrm{U} / \mathrm{L}$, he was diagnosed with rhabdomyolysis.

The patient had experienced multiple prior admissions for rhabdomyolysis over the past 20 years in the setting of CPT-II deficiency secondary to known triggers of heavy exercise, cold exposure, stress and anesthesia.

Other pertinent laboratory findings included: hemoglobin, $12.8 \mathrm{~g} / \mathrm{dL}(13.2-16.6 \mathrm{~g} / \mathrm{dL})$; white blood cell count $4.9 \times 10^{9} / \mathrm{L}\left(3.4-9.6 \times 10^{9} / \mathrm{L}\right)$; platelet count, $229 \times 10^{9} / \mathrm{L}\left(135-317 \times 10^{9} / \mathrm{L}\right)$; sodium, 140 $\mathrm{mmol} / \mathrm{L}(135-145 \mathrm{mmol} / \mathrm{L})$; potassium, 4.3 (3.6-5.2 $\mathrm{mmol} / \mathrm{L})$; bicarbonate, $28 \mathrm{mmol} / \mathrm{L}(22-29 \mathrm{mmol} / \mathrm{L})$; calcium, $8.6 \mathrm{mg} / \mathrm{dL}(8.6-10.0 \mathrm{mg} / \mathrm{dL})$; creatinine, $0.75 \mathrm{mg} / \mathrm{dL}(0.74-1.35 \mathrm{mg} / \mathrm{dL})$; serum urea nitrogen $11 \mathrm{mg} / \mathrm{dL}$ (8-24 mg/dL); glucose, $95 \mathrm{mg} / \mathrm{dL}$ (70-140 $\mathrm{mg} / \mathrm{dL})$; total bilirubin, $1.0 \mathrm{mg} / \mathrm{dL}(<1.2 \mathrm{mg} / \mathrm{dL})$; direct bilirubin, $0.2 \mathrm{mg} / \mathrm{dL}(<0.3 \mathrm{mg} / \mathrm{dL})$; alanine aminotransferase, $272 \mathrm{mg} / \mathrm{dL}$ (7-55 U/L); aspartate aminotransferase, $803 \mathrm{U} / \mathrm{L}$ (8-48 U/L); alkaline phosphatase, $120 \mathrm{U} / \mathrm{L}$ (40-129 U/L); nasopharynx swab, SARS-CoV-2 RNA undetected.

The patient was admitted to the general internal medicine service and initiated on treatment for rhabdomyolysis, including intravenous levocarnitine $1 \mathrm{~g}$ three times daily, intravenous $10 \%$ dextrose in water at $200 \mathrm{cc} / \mathrm{hr}$ along with an insulin drip to maintain glucose less than $200 \mathrm{mg} / \mathrm{dL}$. By the time of discharge roughly 72 hours later, his creatine kinase was 1,653 U/L.

\section{DISCUSSION}

\section{Clinical manifestations}

CPT-II deficiency has a wide range of clinical manifestations ranging from asymptomatic to intermittent myalgias to recurrent rhabdomyolysis. 
Onset is typically in late childhood or early adulthood with single or multiple attacks of severe myalgia, which is commonly triggered by exercise. Unlike many other muscular pathologies, no signs of myopathy, such as myalgia or weakness, are typically seen between acute episodes of disease. [1] Heterozygous carriers of disease do not typically exhibit any symptoms and no studies have examined exercise or stress thresholds in this population.

Rhabdomyolysis is a life-threatening pathology with potential for long-term complications without prompt treatment, including renal failure. Like other causes of acute renal failure, the electrolyte derangements commonly seen with rhabdomyolysis include anion gap metabolic acidosis, hyperkalemia, hyperphosphatemia, and hypocalcemia. Transaminitis is also often seen in rhabdomyolysis primarily due to release of AST and ALT from muscle, although it is important to rule out any coexisting liver disease. In a 2010 study including 673 patients, elevations in AST and ALT were observed in $95 \%$ and $73 \%$ of rhabdomyolysis cases, respectively, which is consistent with known AST-predominance in muscle tissue. [2] Furthermore, despite conventional thinking that AST/ALT elevation may be further increased by renal insufficiency in the setting of rhabdomyolysis, studies have shown decreased transaminases in patients with a lower glomerular filtration rate given hepatic clearance of enzymes. [3]

\section{Diagnosis}

Clinical decompensation with rhabdomyolysis is often the manifestation leading to initial diagnosis of disease. Serum creatine kinase elevation is a sign of muscle injury and it is generally accepted that creatine kinase greater than 5-10 times the upper limit of normal is sufficient for diagnosis of rhabdomyolysis. [4] Similar to its clinical presentation, the laboratory presentation of CPT-II deficiency involves normal creatine kinase levels between acute attacks of disease in at least $90 \%$ of patients, which hinders diagnosis in healthy individuals. [5] Muscle biopsy may be useful outside of the acute setting for determining the etiology of rhabdomyolysis, but it is not useful in diagnosis of acute rhabdomyolysis, and thus, it should not be included in routine workup of disease. [6]

There have been several hundred different mutations associated with CPT-II deficiency leading to partial loss of enzyme activity and/or enzymatic dysregulation; however, the p.Ser113Leu mutation is identified in about $70 \%$ of mutant alleles and is exclusive to the adultform of disease. [7] High-performance liquid chromatography (HPLC) tandem mass specAtrometry of plasma samples will demonstrate elevations in long-fatty acid chains (C12-C18) with Hexadecanoyl-L-carnitine (C16) and Octadecenoyl-L-carnitine (C18:1) most common in CPT-II deficiency. Although abnormal lipid accumulation patterns may be seen in muscle biopsy and T1-weighted magnetic resonance imaging (MRI), these techniques are not sufficient for diagnosis of CPT-II deficiency. [1]

Initial diagnosis of CPT-II deficiency in our patient was confirmed via genetic testing. Plasma samples showed elevations in long-chain acylcarnitines, especially C16 (1.01 nmol/mL; reference range $<0.23 \mathrm{nmol} / \mathrm{mL}$ ) and $\mathrm{C} 18: 1$ species $(1.12 \mathrm{nmol} / \mathrm{mL}$; reference range $<0.39$ $\mathrm{nmol} / \mathrm{mL}$ ), which is indicative of either carnitineacylcarnitine translocase (CACT) deficiency or CPT-II deficiency. Given adult-onset of disease, CPT-II deficiency was the most likely diagnosis.

\section{Treatment}

There is currently no curative treatment for CPT-II deficiency. Prevention of renal failure, correction of electrolyte disturbances to avoid lifethreatening arrythmias, and halting of further muscle breakdown are the goals of treatment. Early, aggressive intravenous fluid resuscitation with crystalloids is the primary treatment and standard of care for treating rhabdomyolysis. It can improve hypovolemia, acute renal failure, and clearance of myoglobin. The ideal fluid for rhabdomyolysis remains controversial; however, normal saline and lactated ringers are most utilized. [8] Intravenous sodium bicarbonate has been theorized to alkalinize urine to reduce myoglobin precipitation, although prior studies have not demonstrated significant benefit. [9]

Continuous renal replacement therapy (CRRT) and hemodialysis have been investigated in previous studies as therapeutic interventions for rhabdomyolysis aimed to remove muscle breakdown products (e.g., myoglobin) to prevent subsequent acute renal failure regardless of traditional indications for dialysis; however, studies have shown no meaningful reduction in acute renal failure or mortality benefit. Although corticosteroid therapy is the gold standard for treatment of inflammatory myopathies (such as 
polymyositis) and published reports showed some success with their use in the setting of CPT-II, there is currently no strong evidence to support administration of corticosteroid therapy for rhabdomyolysis unrelated to inflammatory myositis. [10,11]

Complete body rest and carbohydrate supplementation are useful in diminishing the severity of symptoms during an acute attack of CPT-II. Avoidance of strenuous physical activity is advised; however, long-term avoidance of exercise altogether is ill-advised due to the associated increased risk of cardiovascular disease. A carbohydrate-rich diet with low fat content can shift the nutrient deficiency to help avoid hypoglycemia and arrhythmias related to metabolic disturbances. [1]

Recent innovations in gene therapy for other inherited musculoskeletal diseases, such as spinal muscular atrophy, may indicate a future route of targeting curative treatment for CPT-II deficiency.

\section{CONCLUSION}

Recurrent rhabdomyolysis is the most common clinical manifestation of CPT-II deficiency requiring hospitalization. Given the nonspecific signs and symptoms of rhabdomyolysis with a wide spectrum of severity, diagnosis requires a high index of clinical suspicion and integration of patient history, clinical manifestations, and laboratory evaluation. Furthermore, recognition of the etiology of rhabdomyolysis is essential in implementing proper therapy. Treatment of rhabdomyolysis secondary to CPT-II deficiency centers on early, intravenous fluid resuscitation, correction of electrolyte abnormalities, complete body rest, and carbohydrate and carnitine supplementation.

\begin{abstract}
$\overline{\text { Deficitul de carnitin palmitoiltransefrază II, o maladie autozomală recesivă, este }}$ cea mai frecventă cauză de rabdomioliză recurentă la adulți. Recunoașterea și evitarea factorilor declanşatori, cum sunt stresul sau efortul fizic susținut, reprezintă cheia pentru prevenția viitoarelor episoade. In ciuda acestor aspecte, mulți pacienți continuă să prezinte simptome recurente incluzând episoade de rabdomioliză. Scopul tratamentului este evitarea dezvoltării insuficienței renale și corecția dezechilibrelor electrolitice. Este esențial ca această patologie să fie recunoscută în contextul clinic. Prezentăm cazul unui pacient cu deficit de CTP-II cu episoade de rabdomioliză recurentă.
\end{abstract}

\footnotetext{
Correspondence to: Razvan M. Chirila, MD, Division of General Internal Medicine, Mayo Clinic, 4500 San Pablo Road, Jacksonville, FL 32224, USA

E-mail: Chirila.Razvan@mayo.edu

Phone 904-953-2824 Fax 904-953-2848

Acknowledgements: None

Conflict of interest disclosure: The authors declare that there are no conflicts of interest.
}

\title{
REFERENCES
}

1. JOSHI PR, ZIERZ S. Muscle Carnitine Palmitoyltransferase II (CPT II) Deficiency: A Conceptual Approach. Molecules.2020;25(8).

2. WEIBRECHT K, DAYNO M, DARLING C, BIRD SB. Liver aminotransferases are elevated with rhabdomyolysis in the absence of significant liver injury. J Med Toxicol. 2010;6(3):294-300.

3. RAY L, NANDA SK, CHATTERJEE A, SARANGI R, GAGULY S. A comparative study of serum aminotransferases in chronic kidney disease with and without end-stage renal disease: Need for new reference ranges. Int J Appl Basic Med Res. 2015;5(1):31-5.

4. BOSCH X, POCH E, GRAU JM. Rhabdomyolysis and acute kidney injury. N Engl J Med. 2009;361(1):62-72.

5. WIESER T, DESCHAUER M, OLEK K, HERMANN T, ZIERZ S. Carnitine palmitoyltransferase II deficiency. Molecular and biochemical analysis of 32 patients. Neurology. 2003;60(8):1351-1353.

6. NANCE JR, MAMMEN AL. Diagnostic evaluation of rhabdomyolysis. Muscle Nerve. 2015;51(6):793-810.

7. JOSHI PR, DESCHAUER M, ZIERZ S. Carnitine palmitoyltransferase II (CPT II) deficiency: genotype-phenotype analysis of 50 patients. J Neurol Sci. 2014;338(1-2): 107-11.

8. MANSPEAKER S, HENDERSON K, RIDDLE D. Treatment of exertional rhabdomyolysis in athletes: a systematic review. JBI Database System Rev Implement Rep. 2016;14(6):117-47.

9. SOMAGUTTA MR, PAGAD S, SRIDHARAN P, NANTHAKUMARAN S, ARNOLD AA, MAY V et al., Role of Bicarbonates and Mannitol in Rhabdomyolysis: A Comprehensive Review. Cureus. 2020;12(8):e9742-e9742. 
10. ANTOON JW, CHAKRABORTI C. Corticosteroids in the treatment of alcohol-induced rhabdomyolysis. Mayo Clin Proc. 2011. 86(10):1005-7.

11. SUMMERLIN ML, REGIER DS, FRASER JL, CHAPMAN KA, KAFASHZADEH D, BILLINGTON C et al., Use of dexamethasone in idiopathic, acute pediatric rhabdomyolysis. Am J Med Genet A. 2021;185(2):500-507.

Received $20^{\text {th }}$ May 2021 